\title{
The evolution of the 'public' in diplomacy
}

\author{
Christina la Cour
}

\begin{abstract}
Should diplomacy be public? The answer to this question, as well as the understanding of what 'public diplomacy' means, has evolved over time. Through the lenses of a Quentin Skinner inspired framework, this paper presents the findings from a comprehensive study of four influential historical answers to the question, articulated respectively by Woodrow Wilson, Harold G. Nicolson, Henry A. Kissinger and Joseph S. Nye. Each scholar operates with a distinct conceptualization of 'public' and 'public diplomacy'. These conceptualizations vary in terms of who, what, and how 'the public' is, as well as what it means to manoeuvre 'in public'. Resulting from differing conceptualizations of 'public', the four scholars advocate very different forms of 'public diplomacy', and their respective attitudes to public diplomacy diverge. Beyond demonstrating the broad range of variance in historical conceptions of public diplomacy, the paper presents one main finding: The meaning of 'public' has generally kept expanding since the beginning of the twentieth century, but the notion of public diplomacy has changed from referring to the conduct of 'diplomacy in the open' to a special form of diplomatic activity where diplomats communicate directly to foreign publics.
\end{abstract}

\section{Introduction}

The controversial webpage WikiLeaks comprises millions of documents in a so-called "Public Library of US diplomacy". This is no coincidence: WikiLeaks' founder, Julian Assange, is a firm believer in public diplomacy. As he puts it: "If war can be started by lies, they can be stopped by truths" (Assange 2011). His standpoint is strongly opposed by prominent figures like President Obama and former secretary of state Hillary Clinton (BBC News 2010; CNN 2010). Following a large leak in 2010, Clinton deemed the leaks a threat to diplomatic activity: “This disclosure is not just an attack on America's foreign policy; it is an attack on the international community, the alliances and partnerships, the conventions and negotiations that safeguard global security and advance economic prosperity" (CNN 2010). Ostensibly, to Assange, the concept of public diplomacy invokes a diplomacy which is open to the (global) public. To Clinton, public diplomacy means diplomacy which is working in favor of the public interest. To Assange, however, open diplomacy is in the public interest. The dispute between Assange and Clinton demonstrates how 'public diplomacy' is still a contentious topic. Yet, on a more fundamental level, the debate exposes how public diplomacy is an ambiguous concept with multiple meanings. As the diplomacy scholar Paul Sharp notes, "we remain unsure about what is meant by people, the people, and, especially, who are the public in public diplomacy?” (Sharp 2009, 6). It is the purpose of this paper 
to address Sharp's question. The aim is to increase transparency about different historical uses of the word 'public' and its evolution in the diplomacy literature. By portraying historical uses of 'public', the analysis teases out some of the commonly overlooked ambiguities of the concept of public diplomacy.

The paper asks how leading scholars of diplomacy have conceptualized 'public' and 'public diplomacy' since the beginning of the $21^{\text {th }}$ century? To answer this, the work of four influential scholars of diplomacy is scrutinized: Woodrow Wilson (1856-1924), Harold G. Nicolson (1886-1968), Henry A. Kissinger (1923-) and Joseph S. Nye (1937-). Aside from being significant scholars of diplomacy, each of these four scholars have engaged with the question of 'the public in diplomacy' and their engagement has in turn contributed to the historical evolution of the understanding public diplomacy.

The analysis was conducted using a framework inspired by the conceptual historian Quentin Skinner. Skinner's approach assumes texts are speech acts, written to legitimize new practices. Hence, the approach was useful to illuminate how different conceptualizations of 'public' in the diplomacy literature legitimized various types of public diplomacy. Skinner's methodological guidelines served as a basis for the development of three types of analytical strategies applied to study the evolution of 'public' in the diplomacy literature: A structured context analysis for each thinker, a quantitative-inductive coding analysis of each thinker's use of the term 'public', and an analysis based on a kind of 'contextual hermeneutics'.

This article begins with a review of international relations literature dealing with the topic of diplomacy. Subsequently, Skinner's theory of interpretation of conceptual history is introduced. The next section lays out the methods derived from Skinner's theory, which have been applied in the analysis, followed by a summary of the results of the analysis. This section is divided into five subsections describing variations in the four scholars' conceptualization of 'public' in diplomacy. Finally, the paper concludes that the range of meanings which the concept of 'public' covers has generally expanded in the diplomacy literature, while the notion of public diplomacy has changed from referring to the conduct of 'diplomacy in the open' to a special form of diplomatic activity, where diplomats communicate directly to foreign publics.

\section{Literature review}

It is hardly a controversial observation that modern international relations theories of various strands have tended to neglect the study of diplomacy. The absence of diplomacy studies in the international

\footnotetext{
${ }^{1}$ This is a condensed version of a larger study undertaken by the author as part of a Master Programme in Political Science at the University of Copenhagen (2016), supervised by Professor Rebecca Adler-Nissen.
} 
relations literature is in part due to a stern focus on the 'system level' of state interaction. There are, however, a few exceptions worth mentioning: The English School, game theory approaches to diplomacy, and the "public diplomacy" literature. These three strands of literature all include diplomacy either as a variable or an institution. Thus, all three strands offer incidental insights concerning how the relationship between diplomacy and the public has been theorized.

The English School viewed diplomacy as "the master-institution of international relations" (Neumann 2003, 350; Wight and Bull 2002 [1979]). From an English School perspective, the tensions between realism, rationalism and revolutionism also characterize the conduct of public diplomacy. On the one hand the diplomat has a moral obligation to include the public in diplomacy. On the other hand, inclusion of the public could compromise the chance of retaining the international order. Opening diplomacy to the public is not risk-free, since foreign policies are "so complex, and potentially so dangerous, that they cannot safely be determined by public opinion alone" (Watson 1997: 96). Furthermore, there is a "total inability of international public opinion to affect the march of events" (Wight and Porter 2005: xxxix). The general public is simply incapable of understanding important details in diplomatic negotiations and should therefore mostly be consulted with regard to principle matters (Bull 1961: 114, 136, 191). However, public discussions of principles often end in gridlock - unlike secret diplomatic negotiations that implicate "compromise and understanding of the other man's point of view" (Watson 1991: 80).

A significantly different perspective on diplomacy is provided by game theory or negotiation theory approaches to the study of diplomacy. For example, Thomas Schelling's strategic realism (1958) depicts diplomacy as an instrument mostly used during negotiations between states. In his model, the public only plays a role in diplomacy to the extent that it may affect the incentive structure in the diplomatic negotiations. In a similar vein, James Fearon has conceptualized the public as a cost - for example, he describes "the audience costs created by public displays of force" (Fearon 1994: 242). Composing the 'diplomatic game' slightly different, Robert Putnam (1988) considers public opinion to be a form of domestic 'player' in line with other domestic groups fighting to influence the mandate given to diplomatic negotiators.

A final strand of literature is the so-called 'public diplomacy' literature, which is particularly concerned with the special type of diplomacy that addresses foreign publics. In this tradition, scholars study the means to 'cultivate' foreign publics (see Fisher 1972; Staar 1986). Modern contributions to this literature tend to focus on 'new public diplomacy tendencies', 'citizen diplomacy', 'networked diplomacy' etc. (Melissen 2011; Nye 2010b, 2010a). Scholars of new public diplomacy tend 
to emphasize how diplomacy is conducted on "supranational, national, subnational and transnational levels" (Davis Cross and Melissen 2013: xvii; Huijgh, Gregory, and Melissen 2013).

Although the above-mentioned three strands of literature momentarily consider the role of the public in diplomacy, understanding the role of the public is secondary to the understanding of diplomacy. The conceptualization of the public is derived from diplomacy theory and is not at its core. Therefore, it is necessary to shed more light on the role of the public in diplomacy, which is best approached by conducting a more detailed study of how it has evolved.

\section{Quentin Skinner's approach to conceptual history}

Quentin Skinner's approach to studying the evolution of a concept is, as mentioned, useful both as a theoretical and a methodological starting point. His approach can be described as a theory of interpretation of conceptual history. This theory assumes all texts are speech acts and offers methodological strategies to grasp their intended meaning. In the following, I briefly outline the most important theoretical distinctions from Skinner's theory and the implicated methodological procedures.

A key component of Skinner's theory of interpretation is his focus on the intention of a writer. Unlike other conceptual history approaches ${ }^{2}$ or most forms of discourse analysis, Skinner's recommended text interpretation plays out on two levels: The context and the actor. According to Skinner, focusing only on the context (or the language structure of an epoch) is too deterministic when studying historical meanings of a concept. However, to assume that any concept has an essence which transcends different epochs is equally deficient (Skinner 1969: 35) ${ }^{3}$. The only way to understand the meaning of a text - and in this case the meaning of the word 'public' in the diplomacy literature - is to let the context serve as a "sort of court of appeal for assessing the relative plausibility of incompatible ascriptions of intentionality" (Skinner 1969: 49). Hence, to study the meaning of a concept, one must understand the lingual, societal-political and private context of the writer. Furthermore, conceptual studies should trace the use of a concept rather than its meaning. Focusing on the use sheds light on how the concept has been used to do something by different authors (Skinner 1969: 37). Put differently, studying the use of a concept illuminates how authors contribute to developing the concept. Meaning in concepts can be changed by means of rhetorical re-descriptions and so-called evaluative-descriptive terms which establish, maintain, change or challenge the meaning of a concept (Skinner and Sebastián 2007: 114; Skinner 2009 [2002]: 105).

\footnotetext{
${ }^{2}$ For example, Reinhart Koselleck.

${ }^{3}$ This distinction between focusing on a meaning of a concept and the contextually determined meanings of a concept is sometimes described as textualism versus contextualism.
} 
Skinner's emphasis on how authors do something with concepts derives from his assumption that texts are speech acts. Skinner defines two types of speech acts: illocutionary and perlocutionary. Perlocutionary speech acts are attempts to persuade, scare, inspire etc. They have an intended effect, which may or may not occur (unlike illocutionary speech acts which have constitutive and immediate effects ${ }^{4}$ ). The distinction matters when trying to decipher what kind of behavior (for example a diplomat's behavior) an author attempts to legitimize with his text. To Skinner, texts should always be viewed as attempts to legitimize certain behavior. His theory illuminates the 'legitimizing effects' of a text on historical practices. In the case of this paper, Skinner's theory illuminates how four diplomacy scholars have legitimized different relationships between the public and diplomacy.

\section{Methods}

The findings presented in this paper derive from a comprehensive study of carefully selected books and articles written by Woodrow Wilson, Harold Nicolson, Henry Kissinger and Joseph Nye. The articles and books selected for analysis were chosen based on a careful screening of secondary literature and explorative reading with the intention of maximizing the extent to which the topic of public diplomacy was considered by each author (see appendix for more details on the selection process and a full list of the books and articles analyzed). Three analytical strategies were employed to reach the findings presented in the next section, all derived from Skinner's theory of interpretation: Contextual analysis, a 'concept-use-analysis', and an informed hermeneutic. The contextual analysis mapped the four authors' personal, societal and lingual context. ${ }^{5}$ Especially, the contextual analysis illuminated the practicalpolitical problems related to the conduct of diplomacy at the time of Wilson, Nicolson, Kissinger and Nye. This step enabled the use of their contexts as 'courts of appeal' for the interpretation of what they meant by 'public'. The 'concept-use-analysis' involved a systematic study of the different uses of the word public in different texts produced by the four scholars (see appendix for a quantitative summary for the uses of the word public). This analysis entailed a form of text reading with a narrow focus. The reading paid attention to the following issues: 1) what kind of sentences the word 'public' appeared in 2) what types of arguments the word public was used in 3) the word combinations that 'public' appeared in and 4) what was done with these word/sentence combinations. The concept-use-analysis provides an overview of how the four scholars used the word public is in combination with descriptive-

\footnotetext{
${ }^{4}$ A typical example of an illocutionary speech act is a baptism: The effect of the speech act is constitutive. The child gets a name as a constitutive effect of the uttering of the words "I hereby name you".

${ }^{5}$ Due to limited space in this paper, the contextual analysis is only very briefly summarized, and the private and lingual context analyses are only summarized indirectly. However, the contextual analysis served as a 'court of appeal' or 'background knowledge' for the interpretations made and thus the findings summarized in the paper.
} 
evaluative terms that re-described the nature and role of the public in diplomacy. Finally, building on the first two analytical strategies, the informed hermeneutic analysis was employed to tease out the types of diplomacy the scholars sought to legitimize. The strategy was used as a kind of hermeneutic 'reading' of the four authors' texts, moving between the whole (their context) and the parts (the texts) (Burns 2011; Skinner 1975). The hermeneutic reading revealed how the four scholars' use of the concept of 'public' legitimized different forms of diplomacy, both including and excluding the public from diplomacy. In the next section, I summarize the findings deriving from each of the three analytical strategies just presented.

\section{The evolution of the 'public' in diplomacy}

It only takes a brief screening of the diplomacy literature to discover how the question of 'public diplomacy' has been considerably salient since the beginning of the twentieth century. Wilson, Nicolson, Kissinger and Nye all faced some level of moral obligation to make diplomacy public. However, as the analysis summarized in this section demonstrates, they interpreted this obligation in different ways. The following section expands on their differences. The first section depicts the main differences in their contexts. The next section sheds light on differences concerning 'who and what' the public were/was to each scholar. The third section elaborates how each scholar associates the public with different characteristics. The fourth section describes how each scholar understood what 'public diplomacy' involved. And finally, the fifth section considers the answers of each scholar concerning the question of whether diplomacy should be public.

\subsection{Four different contexts}

War and technological advances are arguably the two most important drivers of the evolution of diplomatic conduct in the modern era. Technology contributed to the transformation not only of diplomacy, but also the ways in which it was possible to give the public access to diplomatic activities. At the same time, the challenges of armed conflict, which each writer hoped diplomacy could solve, changed character. More specifically, the challenges of armed conflict shifted from great world wars to new 'types' of war such as cold war, hybrid war and war against terrorism.

Table a: Contextual factors of the four scholars

\section{Wilson}

Nicolson
Kissinger

Nye 


\begin{tabular}{|lllll|}
\hline $\begin{array}{l}\text { Main challenge } \\
\text { of the time }\end{array}$ & World War I & World War I and II & $\begin{array}{l}\text { The Cold War and } \\
\text { the Vietnam War }\end{array}$ & $\begin{array}{l}\text { Power vacuum } \\
\text { following the Cold } \\
\text { War, the threat of } \\
\text { terrorism }\end{array}$ \\
\hline $\begin{array}{l}\text { Communication } \\
\text { technology }\end{array}$ & $\begin{array}{l}\text { Telegraph and } \\
\text { (telephone and } \\
\text { radio invented } \\
\text { but not } \\
\text { commonly used) }\end{array}$ & $\begin{array}{l}\text { Radio (more widely } \\
\text { spread) }\end{array}$ & TV (widely spread) & $\begin{array}{l}\text { The Internet } \\
\text { (during the later } \\
\text { part of his } \\
\text { scholarship) }\end{array}$ \\
\hline
\end{tabular}

In 1918, one year after the United States entered the First World War to "make the world safe for democracy" (Wilson 1917a), president Woodrow Wilson gave a famous speech outlining fourteen principles on which he believed a new, stabile and peaceful world order could be built (Wilson 1917a, 1918a). In this speech, Wilson addressed what he believed to be the crucial problem of his own time: large-scale territorial conflicts. To Wilson, wars could be prevented if the public had a say in foreign affairs. Permanent peace could only be achieved by establishing an international order "under which reason and justice and the common interests of mankind" prevailed (Wilson 1918b). Hence, when the war ended, Wilson travelled to Paris to negotiate the Versailles Peace Treaty. Wilson stayed in Paris for six months, and during that time the main information channels from Paris to Washington were letters and the telegraph (and to a minor degree the telephone).

At the beginning of his career as a British diplomat, Harold Nicolson also participated in the Versailles Negotiations. Thereafter, Nicolson worked as a diplomat before shifting his focus to domestic politics and the economic crisis in Britain in the 1930s. As the Second World War broke out, Nicolson redeployed his writing to the international sphere. After the end of the war, Nicolson reported from the 1946-47 peace negotiations in Paris. Here, Nicolson witnessed how the dissemination of radio broadcasting influenced the conduct of diplomatic negotiations. Nicolson's diaries from 1946-1947 offer a more pessimistic view on 'open diplomacy' than his diaries from the Versailles negotiations 26 years earlier. The pessimism was associated with the technological advancements of his time. As Nicolson put it: " [] $\mathrm{t}$ is not possible to negotiate in front of the microphone" (Nicolson 1947).

While Nicolson's main concern with regards to technology was the radio, Kissinger saw the spread of the television and its transmission of the Vietnam War directly into American homes as an obstacle to conducting open diplomacy. Unlike Wilson and Nicolson, Kissinger was not facing the end of a world war but the continuation of the Cold War and the Vietnam War. After serving as 
Secretary of State from 1973-1977, Kissinger wrote his memoirs ${ }^{6}$ in which he described how a back channel facilitated high-level secret communications, which supplemented the official nuclear disarmament talks with the Kremlin. Furthermore, Kissinger secretly met with North Vietnamese officials in Paris in 1970 and travelled secretly to China in 1971 to conduct secret talks with the Mao regime. Although practising secret diplomacy was not new to the White House, the Nixonadministration was arguably practicing it more actively than any previous US governments ${ }^{7}$.

Finally, the invention of the Internet, and its rapid global diffusion, is an important concern in Joseph Nye's scholarship. After the fall of the Berlin wall, new types of global threats arose, and Nye's texts reveal much concern with the possibilities and challenges intrinsic to a modern information society. In 1990, Joseph Nye first coined the concept of 'soft power' (Nye 1990). As American popularity decreased during the war in Iraq from 2003 onwards, Nye emphasized the need to conduct 'public diplomacy' or 'new public diplomacy' in order to increase American soft power (see for example Nye 2010a, 2010b). However, as we shall see in the next section, his notion of public diplomacy differs significantly from what Wilson, Nicolson and Kissinger meant.

\subsection{The public: Who is it?}

According most contemporary English dictionary definitions, the word 'public' has three common connotations today. It is used to refer to a) the people/the republic (the people-connotation) b) to describe a quality of a statement or performance as being in open view (the quality-connotation) or c) as something belonging to the public, i.e. state institutions (the ownership-connotation). This section considers the people-connotation.

Table b: The Public - who is it?

\begin{tabular}{|lllll|}
\hline & Wilson & Nicolson & Kissinger & Nye \\
\hline $\begin{array}{l}\text { Who the } \\
\text { public is }\end{array}$ & $\begin{array}{l}\text { Educated male } \\
\text { citizens }\end{array}$ & $\begin{array}{l}\text { Educated citizens } \\
\text { (men and women) }\end{array}$ & All citizens & All citizens \\
& $\begin{array}{l}\text { The people of a } \\
\text { nation }+ \text { the people } \\
\text { of the world }\end{array}$ & $\begin{array}{l}\text { The people of a } \\
\text { nation }\end{array}$ & $\begin{array}{l}\text { The people of a } \\
\text { nation }\end{array}$ & $\begin{array}{l}\text { The people of a nation } \\
+ \text { the people of 'all } \\
\text { other nations' }+\end{array}$ \\
\hline
\end{tabular}

\footnotetext{
${ }^{6}$ Kissinger's memoirs consist of three volumes, The White House Years (1979), Years of Upheaval (1982) and Years of Renewal (1999). Particularly the first volume discusses the use of back-channel diplomacy.

7 To the best of my knowledge, no one has conducted a systematic comparison of the extent of various US governments' use of back-channel diplomacy. However, President Nixon himself stated in 1971 that "[t]here have been more backchannel games played in this administration than any in history because we couldn't trust the goddamned State Department" (US Office of the Historian 2017).
} 
When using the people-connotation, the group of people whom Wilson refers to is the educated citizens who he believed had the democratic right to influence foreign policy. In other words, to Wilson, the public was mainly 'educated men'. This narrow range was expanded when Nicolson included more citizens (for example women). The groups were expanded even more under Kissinger and Nye in accordance with the general expansion of suffrage over time. With regards to the geographical boundaries of the public, Wilson already had a very broad conception of the public as having a 'global range'. This 'global range-conceptualization' is also evident in Nicolson and Kissinger's writings. However, both Nicolson and Kissinger tend to focus more on their respective national publics in the works analysed (see appendix for more details). In Nye's writings, the focus on the 'global range' of the public is (re-)introduced as Nye discusses the transnational entities or just 'foreign public opinion' (see for example Nye 2004: 255, 2008, 95, 103). For example, Nye addresses the need to attract moderate Muslims as well as Europeans and Asians (see for example Nye 2009: 163, 2002, 238).

\subsection{The characteristics of the public}

This section summarizes the characteristics, which the four scholars associate with the public ${ }^{8}$. The historic justifications for or against public diplomacy are intrinsically linked to how the scholars perceived the characteristics of the public.

Table c: The characteristics of the public

\begin{tabular}{|c|c|c|c|c|}
\hline & Wilson & Nicolson & Kissinger & Nye \\
\hline \multirow[t]{2}{*}{$\begin{array}{l}\text { The public } \\
\text { (characteristics) }\end{array}$} & $\begin{array}{l}\text { A spiritual entity, } \\
\text { occasionally } \\
\text { personified in a } \\
\text { strong leader who } \\
\text { interprets the 'true } \\
\text { spirit' of the citizens }\end{array}$ & $\begin{array}{l}\text { A volatile, } \\
\text { irrational and } \\
\text { emotional entity } \\
\text { lacking } \\
\text { knowledge of } \\
\text { foreign affairs }\end{array}$ & $\begin{array}{l}\text { An entity } \\
\text { susceptible to } \\
\text { propaganda, but } \\
\text { difficult to control }\end{array}$ & $\begin{array}{l}\text { An entity tending to grow nervous } \\
\text { about foreign affairs - a } \\
\text { nervousness which leads to a } \\
\text { disengagement. }\end{array}$ \\
\hline & $\begin{array}{l}\text { An entity which } \\
\text { constitutes the heart- } \\
\text { blood of the } \\
\text { democratic self- } \\
\text { determination }\end{array}$ & $\begin{array}{l}\text { An entity which } \\
\text { can be educated }\end{array}$ & $\begin{array}{l}\text { An entity with } \\
\text { almost militaristic } \\
\text { behaviour } \\
\text { An entity which is } \\
\text { a piece in an } \\
\text { international } \\
\text { power game }\end{array}$ & $\begin{array}{l}\text { An entity with emotional abilities, } \\
\text { e.g. the ability to be attracted to or } \\
\text { appalled by cultural elements or } \\
\text { rational arguments }\end{array}$ \\
\hline
\end{tabular}

\footnotetext{
${ }^{8}$ The characteristics summarized are used in line with both the 'people-connotation' of the word public.
} 
A key difference between the characteristics, which the scholars relate to the public, concerns the ability to make wise foreign policy choices. Wilson found that not only was the public able to comprehend foreign policy, but it was also "the heart-blood of self-determination" (Wilson 1917b). The democratic publics could, according to Wilson, make wiser choices than power-lusting elites (Wilson 1917b). Nicolson shares part of Wilson's optimism, although with some reservations. To Nicolson, the public can be educated to understand foreign affairs. However, the public is also a somewhat 'spiritual' creature in Nicolson's view, often volatile, irrational and emotional, and sometimes even "foolish and ill-informed" with deficient knowledge of foreign affairs (see for example his descriptions in Nicolson 1934: 402; 1935: 601). These characteristics reappear in Kissinger's depiction of the public. To him, the public is very emotional and acts almost aggressively (see for example references to 'public sentiments' and 'the public mood', Kissinger 2011 [1979]: 363). For example, Kissinger describes the public protestors in Washington demonstrating for peace in Vietnam as a "dormant beast" (Kissinger 2011 [1979]: 1722). According to Kissinger, the strong emotions make publics susceptible to propaganda." Sometimes Kissinger even characterized the public as a 'piece' in a power game; for example when he referred to North Vietnamese comments on public support (or the lack thereof) as a tactic to put pressure on the secret negotiations (Kissinger 2011 [1979]: 763; 1994: 1177).

Although Nye shares the opinion that the public has emotions and can be swayed by attractive cultural means, Nye also finds that the public is partly rational and can be persuaded by rational arguments. Nye shares the worry that the public tends to get nervous about foreign affairs. However, like Nicolson, he finds that the solution is to make the public more informed and educated rather than excluding it from diplomacy. Nervousness can be overcome and knowledge of foreign affairs should lead publics to make wise decisions (Nye 2002: 234). Nye is thus slightly more optimistic about the ability of the public to understand foreign policy. In fact, he is so optimistic that he also believes publics should partake in diplomatic activities by becoming a kind of 'civil diplomat' (Nye 2010b).

There was thus an evolution from the beginning of the century where Wilson had a very optimistic view on the public as highly capable of understanding foreign policy, towards a somewhat pessimistic view at the end of the 1970s. This pessimism was, however, rolled back in the 1990s.

\footnotetext{
${ }^{9}$ Kissinger refers repeatedly to the threat of propaganda when reflecting on the secret talks conducted with 'Kremlin' and 'Hanoi' in his book The White House Years from 1979.
} 


\subsection{What public diplomacy involves}

When discussing public diplomacy, the 'quality-connotation' (a quality or of a statement) is used a lot. The conception of what it involves to conduct public diplomacy (in the meaning of 'diplomacy in open view') expanded as technologies advanced: When Wilson spoke about "open covenants openly arrived at", he meant that democratically responsive diplomats should make decisions for the people they represented, but not that the public ear should be present at the negotiations; this was not technologically feasible at the time (Wilson 1918a). When Wilson opposed "private understandings" he opposed agreements reached between "little groups of ambitious men who were accustomed to use their fellow men as pawns and tools" (Wilson 1917b). To him, negotiating in public did not necessarily involve allowing the press access to negotiations. ${ }^{10}$ Nicolson had a broader conception of what it meant to conduct public negotiations. Although he too did not equate the press with the public, conducting diplomacy in public, to him, meant in the presence of the press (for comments on the broadcast negotiations see Nicolson 1947, 1948, 1954, 1961). This view is echoed in Kissinger and Nye's writings.

Table d) What public diplomacy is

\begin{tabular}{|c|c|c|c|c|}
\hline & Wilson & Nicolson & Kissinger & Nye \\
\hline $\begin{array}{l}\text { What does it mean to } \\
\text { have public } \\
\text { diplomacy? }\end{array}$ & $\begin{array}{l}\text { Sharing of written } \\
\text { opinion statements } \\
\text { between } \\
\text { negotiating } \\
\text { delegations }\end{array}$ & $\begin{array}{l}\text { Diplomatic } \\
\text { conferences where } \\
\text { negotiation takes } \\
\text { place 'in front of } \\
\text { the microphone' } \\
\text { while being } \\
\text { transmitted by radio }\end{array}$ & $\begin{array}{l}\text { The formal } \\
\text { negotiations } \\
\text { happening via } \\
\text { standardized } \\
\text { diplomatic channels } \\
\text { (not necessarily } \\
\text { transmitted via TV } \\
\text { or radio but widely } \\
\text { known to be } \\
\text { occurring) }\end{array}$ & $\begin{array}{l}\text { Directly } \\
\text { addressing the } \\
\text { public with } \\
\text { targeted } \\
\text { communication } \\
\text { and selected } \\
\text { information }\end{array}$ \\
\hline Timing of publicity & $\begin{array}{l}\text { Mandate and } \\
\text { ratification }\end{array}$ & $\begin{array}{l}\text { Mandate and } \\
\text { ratification }\end{array}$ & $\begin{array}{l}\text { 1) After the } \\
\text { diplomatic activities } \\
\text { have been } \\
\text { performed } \\
\text { 2) Occasionally as a } \\
\text { strategic move } \\
\text { during negotiations }\end{array}$ & Constantly \\
\hline $\begin{array}{l}\text { Who should conduct } \\
\text { the diplomatic } \\
\text { activities }\end{array}$ & $\begin{array}{l}\text { State leaders and } \\
\text { diplomats }\end{array}$ & $\begin{array}{l}\text { Diplomats (at least } \\
\text { primarily) }\end{array}$ & $\begin{array}{l}\text { State leaders and } \\
\text { diplomats (but state } \\
\text { leaders conduct the } \\
\text { most important }\end{array}$ & $\begin{array}{l}\text { State leaders, } \\
\text { diplomats, } \\
\text { NGOs, citizens } \\
\text { and private }\end{array}$ \\
\hline
\end{tabular}

${ }^{10}$ The so-called open negotiations were not open to the press, and the final negotiations took place in a hotel room with only the four state leaders of the US, Britain, Italy and France. This happened after the British Prime Minister David Lloyd George had complained about leaks of central documents to the press (Hamilton and Langhorne 2011: 255). 
As listed in table d, there is not just one 'form' of public diplomacy since the public can be included in different diplomatic activities. In Wilson's time, public diplomacy meant that the public (as in the people) had a say about the final deals, but not necessarily oversight of the negotiations. Public access to diplomacy meant that the diplomatic delegations were obliged to state their opinion in writing "on all questions" so that the other diplomatic delegations could be informed about all claims or demands of the country (Nicolson 1933: 234). This exchange of opinion was conducted via microphone in 1946 (Nicolson 1947: 197). Perhaps this explains why Nicolson's writings from 1919 were markedly more optimistic about public diplomacy than his diaries from the negotiations in 1946-47. Twenty-five years after the end of the Second World War, public diplomacy was rhetorically re-described by Kissinger as an ambiguous endeavour: Kissinger uses the 'ownership-connotation' when discussing public diplomacy, and hence, diplomacy was public if it was conducted via the formal public institutions (where the US Congress would have a say). This form of public diplomacy didn't necessarily mean TVtransmitted talks. It just meant that the public was at least informed that talks were occurring (unlike the talks in Kissinger's famous back-channel) (Sebenius and Green 2014; Kissinger 2011 [1979]). Finally, to Nye, public diplomacy completely shifted away from describing negotiations. Although Nye brought the public back into diplomacy, his notion of public diplomacy doesn't necessarily imply public access to all diplomatic activities. Rather, public diplomacy to Nye meant that diplomats should target foreign publics and communicate strategically selected information. Later, Nye's concept of 'new public diplomacy' described a practice where the public (as in the people) should partake in the diplomatic activities by acting as 'civil diplomats' (Nye 2010b).

\subsection{Should diplomacy be public?}

The meanings of 'public' have varied over the past century, and so too have the answers to the question of whether diplomacy should be conducted in public. At the beginning of the twentieth century the answer was mainly positive. During and after the peace negotiations of the 1940s the dominant answer was negative. This lasted until the beginning of the 1990s, when it shifted back to positive. Like the answers, the reasoning behind them has varied. Wilson wanted public diplomacy because he believed public negotiations would constrain narrow interests and thus help prevent war (Wilson 1917b). Nicolson was against public diplomatic negotiations, because publicity obstructed diplomatic negotiations as state leaders took advantage of the occasion to conduct propaganda campaigns instead of searching for compromise (Nicolson 1961: 46-47; 1947: 197). However, Nicolson was not against 
public ratifications of the diplomat's work, that is, public foreign policy. Kissinger was even more pessimistic about public diplomacy than Nicolson. He believed publicity thwarted the chances of gaining trust among the negotiating parties and that public debate could succumb to emotionalism (Kissinger 2011 [1979]: 382). That said, following Kissinger's reasoning, diplomacy was almost by definition somehow public, since even closed negotiations were conducted via publically owned institutions. Finally, Nye's answer to the abovementioned question is overwhelmingly positive. As he takes the omnipresent press as a given, he doesn't view the press as a cause for excluding the public from the diplomacy. On the contrary: The press should be utilized to conduct diplomatic activities.

Table e: Public diplomacy

\begin{tabular}{|c|c|c|c|c|}
\hline & Wilson & Nicolson & Kissinger & Nye \\
\hline $\begin{array}{l}\text { Should diplomacy be } \\
\text { public? }\end{array}$ & Answer is positive & $\begin{array}{l}\text { Answer is mainly } \\
\text { negative }\end{array}$ & $\begin{array}{l}\text { Answer is mainly } \\
\text { negative }\end{array}$ & $\begin{array}{l}\text { Answer is } \\
\text { positive }\end{array}$ \\
\hline \multirow[t]{2}{*}{$\begin{array}{l}\text { The problem with } \\
\text { public diplomacy (or } \\
\text { the lack of inclusion) }\end{array}$} & $\begin{array}{l}\text { The problem with } \\
\text { lacking public } \\
\text { access to } \\
\text { diplomacy: }\end{array}$ & $\begin{array}{l}\text { The problem with } \\
\text { (too much) public } \\
\text { access to } \\
\text { diplomacy: }\end{array}$ & $\begin{array}{l}\text { The problem with } \\
\text { (too much) public } \\
\text { access to } \\
\text { diplomacy: }\end{array}$ & $\begin{array}{l}\text { The problem } \\
\text { with lacking } \\
\text { public access to } \\
\text { diplomacy: }\end{array}$ \\
\hline & $\begin{array}{l}\text { 1) Narrow } \\
\text { interests negotiate } \\
\text { and this leads to } \\
\text { war } \\
\text { 2) The democratic } \\
\text { rights of the } \\
\text { citizens to } \\
\text { influence the state } \\
\text { of affairs are not } \\
\text { respected }\end{array}$ & $\begin{array}{l}\text { 2) Openness blocks } \\
\text { progress of } \\
\text { negotiations }\end{array}$ & $\begin{array}{l}\text { 1) The public } \\
\text { debate involves } \\
\text { emotionalism } \\
\text { 2) Difficult to gain } \\
\text { trust } \\
\text { 3) Need for } \\
\text { confidentiality due } \\
\text { to risk of losing } \\
\text { face }\end{array}$ & $\begin{array}{l}\text { 1) Difficult to use } \\
\text { soft power to } \\
\text { pursue national } \\
\text { interest }\end{array}$ \\
\hline $\begin{array}{l}\text { Which activities } \\
\text { should be public, } \\
\text { which activities should } \\
\text { be secret? }\end{array}$ & $\begin{array}{l}\text { Public: } \\
\text { Negotiations and } \\
\text { conferences }\end{array}$ & $\begin{array}{l}\text { Public: Completed } \\
\text { treaties, subjected } \\
\text { to a referendum }\end{array}$ & $\begin{array}{l}\text { Public: Completed } \\
\text { treaties, subjected } \\
\text { to a referendum }\end{array}$ & $\begin{array}{l}\text { Public: Values, } \\
\text { culture and other } \\
\text { attractive } \\
\text { elements of a } \\
\text { nation }\end{array}$ \\
\hline
\end{tabular}

When raising awareness about the activities which each of the four scholars argued to make public (or keep secret), there seems to be more agreement than one might have expected. The differences 
between the four scholars' attitude towards public diplomacy may derive more from differences in what they understand by practicing public diplomacy than from true differences of opinion. To illustrate, lets briefly consider each scholar again. Wilson promoted public diplomacy. To him, this meant having final agreements subjected to a public vote or ratified by a publically elected congress. Nicolson neither opposed nor promoted including the public in diplomacy but advocated "some mean between secret diplomacy and diplomacy by loudspeaker" (Nicolson 1948: 198). His middle-road rhetoric appears more sceptical than Wilson's. But this is because Nicolson comments on a different form of publicity than Wilson did. Nicolson critiqued radio broadcasted negotiations, and perhaps Wilson would have opposed radio broadcasts as well, if they had been a normal part of communication in his time. It would be wrong to assume Wilson would have supported radio broadcasted negotiations, since the radio-technology wasn't used for such activities in his time. In a different vein, Nye may come across as a stronger proponent of public diplomacy than all three other scholars. In truth, Nye has written some very enthusiastic articles about the advantages of public diplomacy. But when discussing public diplomacy he refers to other activities than, the peace negotiations which Wilson and Nicolson were concerned with or the high-level talks described by Kissinger. To Nye, public diplomacy means communicating strategically to foreign publics; his texts do not include campaigns for increased access to diplomatic negotiations. We can thus not rule out that Nye's proposed public diplomacy would be incompatible with establishing a confidential back channel like the one promoted by Kissinger. However, one important difference worth underlining regards the need for ratification: Whereas both Nicolson and Wilson explicitly emphasize the need for some level of public ratification of diplomatic agreements, Kissinger seems more prone to the view that the President, in his role as representing the public, could negotiate agreements that became effective immediately.

\section{Conclusion}

The analysis of the four historical diplomacy scholars' conceptualizations of 'public' and 'public diplomacy' led to four main findings. Firstly, the understanding of who the public is has evolved over time. The concept has expanded from covering mostly educated men to include the entire adult population (women and men, educated or not). There has also been a development in the understood geographical boundaries of the public; at the beginning of the twentieth century, the public was used by Wilson to refer to a 'global public'. This changed after the Versailles negotiations of 1919 to a narrower and domestic conception of the public. In the 1990s, Nye again started using the term public to describe a more global or transnational entity. 
Secondly, the conceived characteristics of the public have changed throughout the past century (its rationality, its emotional behaviour etc.). The view on the public's capacity to comprehend foreign affairs has shifted back and fourth. Wilson saw the public as being capable of comprehending foreign affairs. Nicolson believed it was possible to educate the public to understand some (but not all) diplomatic activities. Kissinger found the public to be mostly incapable of understanding foreign affairs while Nye again viewed the public as more capable.

Thirdly, the prevailing answer to what it means conduct public diplomacy has changed significantly during the past century. In the early twentieth century, public diplomacy meant negotiations involving the exchange of written statements among diplomats. This definition remained, but was expanded to include statements made via microphone (during the 1940s peace negotiations) and 'in front of the TV' (during the Cold War and still today). However, the notion of public diplomacy also changed its substantial meaning in two ways: Kissinger used it to refer to diplomacy conducted via publicly owned institutions, while Nye used it to describe strategic communications with foreign societies.

Finally, the prevailing attitudes towards the idea of public diplomacy have fluctuated from positive, to negative, and back to positive. But these fluctuating attitudes should be taken with a pinch of salt: Public diplomacy meant something significantly different some hundred years ago than it does today.

\section{References}

Assange, Julian. 2011. Julian Assange Speaking at Trafalgar Square 8th October 2011. Video accessed via YouTube on 1 December 2017 at: https://www.youtube.com/watch?v=RsgSifdbtas.

BBC News. 2010. 'Obama on WikiLeaks Documents', 27 July 2010. Accessed on 18 May 2016 at: http://www.bbc.com/news/av/world-us-canada-10783842/barack-obama-comments-on-wikileaksdocuments.

Bull, Hedley. 1961. The Control of the Arms Race: Disarmament and Arms Control in the Missile Age. London: Weidenfeld \& Nicolson for the Institute for Strategic Studies.

Burns, Tony. 2011. 'Interpreting and Appropriating Texts in the History of Political Thought: Quentin Skinner and Poststructuralism'. Contemporary Political Theory 10 (3):313-31.

CNN. 2010. "Clinton Condemns Leak as “Attack on International Community”, 30 November 2010. Accessed 15 July 2016 at: http://edition.cnn.com/2010/US/11/29/wikileaks/.

Davis Cross, Mai’a K, and Jan Melissen. 2013. European Public Diplomacy: Soft Power at Work. 
Fearon, James D. 1994. 'Signaling versus the Balance of Power and Interests: An Empirical Test of a Crisis Bargaining Model'. The Journal of Conflict Resolution 38 (2):236-69.

Fisher, Glen. 1972. Public Diplomacy and the Behavioral Sciences. Bloomington: Indiana University Press.

Hamilton, Keith, and Richard Langhorne. 2011. The Practice of Diplomacy: Its Evolution, Theory, and Administration. Taylor \& Francis.

Huijgh, Ellen, Bruce Gregory, and Jan Melissen. 2013. 'Public Diplomacy’. Online bibliography accessed on 13 March 2016 at: http://www.oxfordbibliographies.com/display/id/obo9780199743292-0018.

Kissinger, Henry. 1994. Diplomacy. New York: Simon \& Schuster. [Page numbers used for citation refers to the electronic iBook version downloaded via AppleStore]

- 2011. White House Years. First Simon \& Schuster trade paperback ed. New York: Simon \& Schuster trade paperbacks.

Melissen, Jan. 2011. 'Beyond the New Public Diplomacy - 20111014_cdsp_paper_jmelissen.Pdf. http://www.clingendael.nl/sites/default/files/20111014_cdsp_paper_jmelissen.pdf.

Neumann, Iver B. 2003. 'The English School on Diplomacy: Scholarly Promise Unfulfilled'. International Relations 17 (3):341-69.

Nicolson, Harold. 1933. Peacemaking 1919. Boston: Houghton Mifflin Company. 1934. Curzon: The Last Phase 1919-1925 - a Study in Post-War Doplomacy. London: Constable and Co. LTD.

. 1935. 'Modern Diplomacy and British Public Opinion'. International Affairs (Royal Institute of International Affairs 1931-1939) 14 (5):599.

—. 1947. 'Peacemaking at Paris: Success, Failure or Farce?’ Foreign Affairs 25 (2):190-203.

-1948. Comments 1944-1948. London: Constable and Co. LTD.

— 1954. The Evolution of Diplomatic Method. 1. udg. London Constable \& Co. Ltd.

-1961. 'Diplomacy Then and Now'. Foreign Affairs 40 (1):39-49.

Nye, Joseph S. 1990. 'Soft Power'. Foreign Policy, no. 80:153-71.

- 2002. 'The American National Interest and Global Public Goods'. International Affairs (Royal Institute of International Affairs 1944-) 78 (2):233-44.

- 2004. 'Soft Power and American Foreign Policy'. Political Science Quarterly 119 (2):255-70.

- 2008. 'Public Diplomacy and Soft Power'. The Annals of the American Academy of Political and Social Science 616:94-109. 
2009. 'Get Smart: Combining Hard and Soft Power'. Foreign Affairs 88 (4):160-63.

2010a. 'The Pros and Cons of Citizen Diplomacy'. The International Herald Tribune, October 2010, sec. EDIT.

2010b. 'The New Public Diplomacy'. Project Syndicate, 10 February 2010. Accessed on 10 March 2016 at: http://www.project-syndicate.org/commentary/the-new-public-diplomacy.

Putnam, Robert D. 1988. 'Diplomacy and Domestic Politics: The Logic of Two-Level Games'. International Organization 42 (03):427-460.

Schelling, Thomas C. 1958. 'The Strategy of Conflict Prospectus for a Reorientation of Game Theory'. The Journal of Conflict Resolution 2 (3):203-64.

Sebenius, James Kimble, and Laurence Alexander Green. 2014. 'Henry A. Kissinger as Negotiator: Background and Key Accomplishments', December. https://dash.harvard.edu/handle/1/13479072.

Sharp, Paul. 2009. Diplomatic Theory of International Relations. Cambridge: Cambridge University Press.

Skinner, Quentin. 1969. 'Meaning and Understanding in the History of Ideas'. History and Theory 8 (1):3.

1975. 'Hermeneutics and the Role of History'. New Literary History 7 (1):209-32.

2009. 'A Genealogy of the Modern State'. In Proceedings of the British Academy, Volume 162, 2008 Lectures.

Skinner, Quentin, and Javier Fernández Sebastián. 2007. 'Intellectual History, Liberty and Republicanism: An Interview with Quentin Skinner'. Contributions to the History of Concepts 3 (1):103-23.

Staar, Richard Felix. 1986. Public Diplomacy: USA versus USSR. Edited by Hoover Institution on War, Revolution, and Peace. Hoover Press Publication 345. Stanford, Calif: Hoover Institution Press, Stanford University.

US Office of the Historian. 2017. 'Foreign Relations of the United States, 1969-1976, Volume II, Organization and Management of U.S. Foreign Policy, 1969-1972'. Accessed on 1 December 2017 at: https://history.state.gov/historicaldocuments/frus1969-76v02/d29.

Watson, Adam. 1991. Diplomacy: The Dialogue between States. London ; New York, NY: Routledge. 1997. The Limits of Independence: Relations between States in the Modern World. London; New York: Routledge.

Wight, Martin, and Hedley Bull. 2002. Power Politics. Repr. New York: Continuum.

Wight, Martin, and Brian Porter. 2005. Four Seminal Thinkers in International Theory: Machiavelli, Grotius, Kant, and Mazzini. Oxford ; New York: Oxford University Press.

Wilson, Woodrow. 1917a. 'War Message to Congress'. 
1917b. 'Woodrow Wilson: Address to a Joint Session of Congress Requesting a Declaration of War Against Germany'. April 2. Accessed on 7 April at:

http://www.presidency.ucsb.edu/ws/index.php?pid=65366\&st=\&st1=.

1918a. 'Fourteen Points'. Accessed on 7 April at:

http://www.exodusbooks.com/Samples/VP/O3FourteenPoints.pdf.

. 1918b. 'Address to Congress on International Order'. February 11. Accessed on 7 April at: http://www.presidency.ucsb.edu/ws/index.php?pid=110448\&st=\&st1 =.

\section{Appendix}

The selection of publications included in the analysis was informed by the consultation of a broad range of secondary literature (see below). The selection was based on two criteria:

1) The extent to which the author addresses the question of the public in diplomacy in the publication

2) The frequency of the use of the word 'public' appears in the publication

The following tables provide an overview of the literature included in the study, and the extent to which each publication has been analysed. Subsequently, four tables provided details on the different uses of the word public (as they are employed by each scholar).

Publications included in the analysis

Publications by Wilson

\begin{tabular}{|c|c|c|c|c|}
\hline & Publications & Year & Type & Pages \\
\hline \multirow{7}{*}{$\begin{array}{l}\text { Read and } \\
\text { coded }\end{array}$} & Leaders of Men & 1890 & Article & 13 \\
\hline & First Inaugural Address & 1913 & Speech & 3 \\
\hline & Second Inaugural Address & 1917 & Speech & 3 \\
\hline & $\begin{array}{l}\text { Address to a Joint Session of Congress Requesting } \\
\text { a Declaration of } W \text { ar Against Germany }\end{array}$ & 1917 & Speech & 6 \\
\hline & First Annual Message & 1913 & Speech & 4 \\
\hline & Second Annual Message & 1914 & Speech & 7 \\
\hline & Third Annual Message & 1915 & Speech & 11 \\
\hline
\end{tabular}




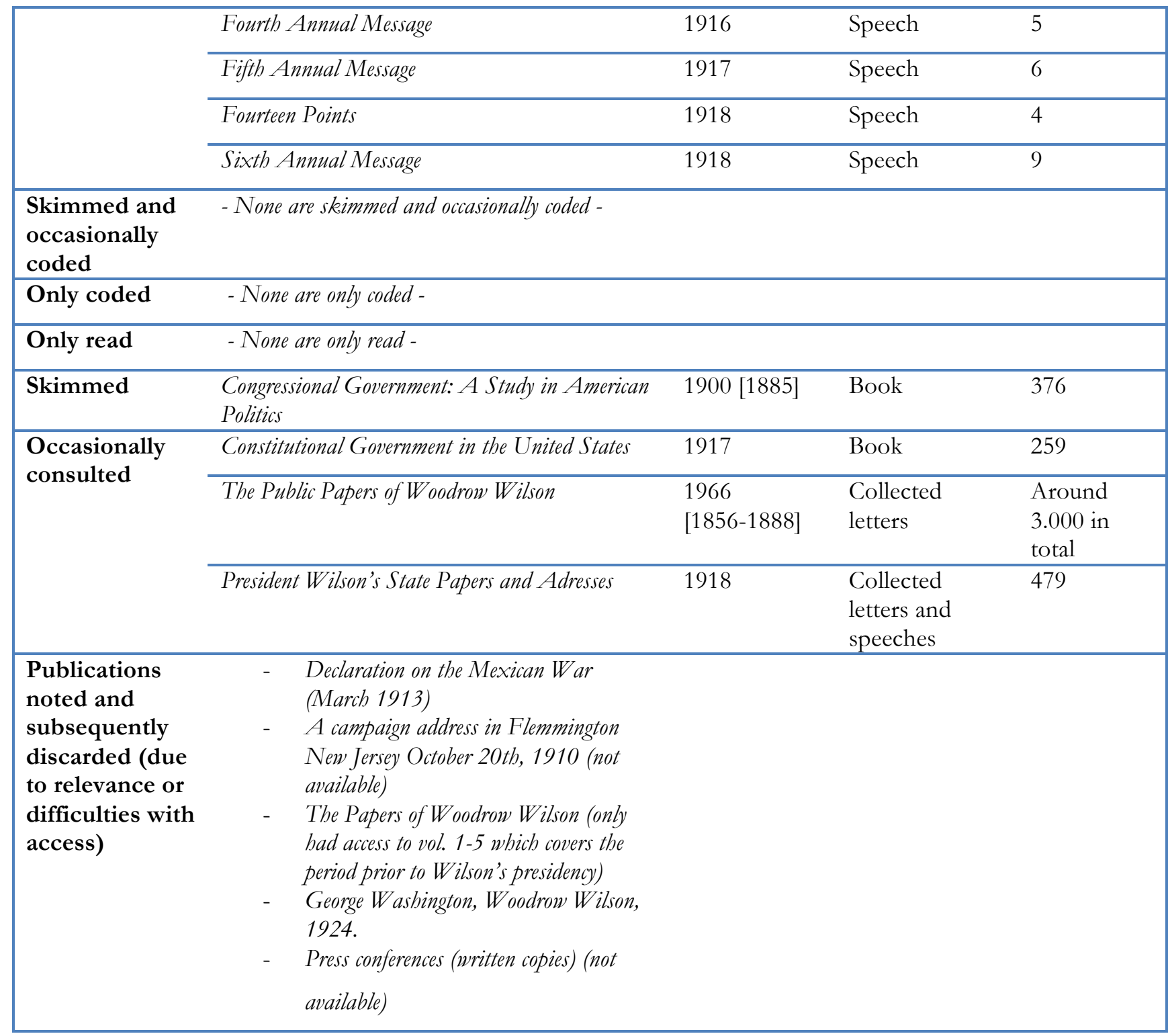

\section{Publications by Nicolson}

\begin{tabular}{|lllll|}
\hline \multicolumn{1}{|l}{$\begin{array}{l}\text { Read and } \\
\text { coded }\end{array}$} & Peacemaking 1919 & Year & Type & Pages \\
& & 1933 & Book (e-book & 371 \\
& & & & \\
\cline { 2 - 5 } & Diplomacy Then and Now & 1961 & Article & 11 \\
\hline $\begin{array}{l}\text { Skimmed and } \\
\text { coded }\end{array}$ & Curzon, The Last Phase & 1937 & Bog (e-book version) & 378 \\
\hline Read & Modern Diplomacy and British Public Opinion & 1939 & Article & 21 \\
\cline { 2 - 5 } & What France means to England & 1939 & Article & 12 \\
\cline { 2 - 5 } & Diplomacy & 1939 & Book & 250 \\
\cline { 2 - 5 } & Peacemaking at Paris: Success, Failure or Farce? & 1947 & Article & 15 \\
\hline
\end{tabular}




\begin{tabular}{|c|c|c|c|c|}
\hline & The evolution of Diplomatic Method & 1954 & Book & 93 \\
\hline & Has Britain a Foreign Policy? & 1935 & Article & 14 \\
\hline \multirow[t]{2}{*}{ Skimmed } & Public Faces & 1932 & Book (novel) & 339 \\
\hline & Men and Circumstance & 1945 & Article & 9 \\
\hline \multirow{3}{*}{$\begin{array}{l}\text { Occasionally } \\
\text { consulted }\end{array}$} & Comments 1944-1948 & 1948 & Book (novel) & 305 \\
\hline & Lord Carnock & 1937 & Book & \\
\hline & Perspectives on peace & 1960 & Book & \\
\hline $\begin{array}{l}\text { Publications } \\
\text { consulted and } \\
\text { subsequently } \\
\text { discarded (due } \\
\text { to relevance or } \\
\text { difficulties with } \\
\text { access) }\end{array}$ & $\begin{array}{ll}\text { - } & \text { Good Behavior (1955) } \\
\text { - } & \text { The English Sense of Humour (1956) } \\
\text { - } & \text { Germany and the Rhineland (1936) } \\
\text { - } & \text { Smalltalk. (1937) } \\
\text { - } & \text { People and Things (1931) } \\
\text { - Anglo-American Misunderstanding } \\
\text { - } \text { Benjamin Constant (1949) } \\
\text { - Marginal Comments - Newspaper articles (not } \\
\text { - Thailable) } \\
\text { - The Harold Nicolson Diaries - collected letters } \\
\text { Unity (1945) }\end{array}$ & & & \\
\hline
\end{tabular}

Publications by Kissinger

\begin{tabular}{|c|c|c|c|c|}
\hline & Publications & Year & Type & Pages \\
\hline \multirow[t]{2}{*}{$\begin{array}{l}\text { Read and } \\
\text { coded }\end{array}$} & $\begin{array}{l}\text { White House Years (1979) (selected chapters } \\
\text { were coded) }\end{array}$ & 1979 & Book & 583 \\
\hline & Diplomacy (1994) (selected chapters were coded) & 1994 & Book & 1144 \\
\hline Only coded & - None were only coded - & & & \\
\hline Only read & American Policy and Preventative $W$ ar & 1955 & Article & 49 \\
\hline Skimmed & A World Restord & 1954 & Ph.D. thesis & 332 \\
\hline \multirow[t]{3}{*}{$\begin{array}{l}\text { Occasionally } \\
\text { consulted }\end{array}$} & For the Record & 1977 & $\begin{array}{l}\text { Collected } \\
\text { works }\end{array}$ & 321 \\
\hline & The Neccessity for Choice & 1960 & Book & 358 \\
\hline & Observations & 1985 & $\begin{array}{l}\text { Collected } \\
\text { works }\end{array}$ & 236 \\
\hline $\begin{array}{l}\text { Publications } \\
\text { consulted and } \\
\text { subsequently } \\
\text { discarded } \\
\text { (due to } \\
\text { relevance or } \\
\text { difficulties } \\
\text { with access) }\end{array}$ & $\begin{array}{ll}\text { - } & \text { World Order (2014) } \\
\text { - } & \text { Does America Need Another Foreign } \\
& \text { Policy? (2001) } \\
\text { - } & \text { Years of Upheaval (1982) } \\
\text { - } & \text { Years of Renewal (1999) }\end{array}$ & & & \\
\hline
\end{tabular}


Publications by Nye

\begin{tabular}{|c|c|c|c|c|}
\hline & Publications & Year & Type & Pages \\
\hline \multirow{6}{*}{$\begin{array}{l}\text { Read and } \\
\text { coded }\end{array}$} & Soft Power (1990) & 1990 & Article & 20 \\
\hline & The American National Interest and Global Public & 2002 & Article & 13 \\
\hline & Goods & & & \\
\hline & Soft power, the means to success in world politics & 2004 & Book & 301 \\
\hline & Public Diplomacy and Soft Power & 2008 & Article & 16 \\
\hline & The New Public Diplomacy & 2010 & Article & 4 \\
\hline \multirow{3}{*}{$\begin{array}{l}\text { Skimmed and } \\
\text { coded }\end{array}$} & Soft power and American Foreign Policy & 2004 & Article & 16 \\
\hline & Get Smart - combining soft power and hard power & 2009 & Article & 5 \\
\hline & A Smarter Superpower & 2009 & Article & 3 \\
\hline \multirow[t]{3}{*}{ Only read } & The War on Soft Power & 2011 & Article & 6 \\
\hline & Do We Want Powerful Leaders? & 2016 & Article & 3 \\
\hline & How Trump Would Weaken America & 2016 & Article & 3 \\
\hline \multirow[t]{4}{*}{ Skimmed } & Why People Don't Trust Government & 1997 & $\begin{array}{l}\text { Book } \\
\text { (edited by } \\
\text { Nye) }\end{array}$ & 281 \\
\hline & $\begin{array}{l}\text { The Place of Soft Power in State-Based Conflict } \\
\text { Management }\end{array}$ & 2007 & $\begin{array}{l}\text { Book } \\
\text { chapter in } \\
\text { the book } \\
\text { Leashing the } \\
\text { Dogs of War }\end{array}$ & 12 \\
\hline & Notes for a soft-power research agenda & 2007 & $\begin{array}{l}\text { Bidrag til } \\
\text { bogen Power } \\
\text { in World } \\
\text { Politics }\end{array}$ & 11 \\
\hline & Culture, Soft Power and Americanization & 2008 & $\begin{array}{l}\text { Bidrag til } \\
\text { bogen } \\
\text { Cultural } \\
\text { Politics in a } \\
\text { Global Age }\end{array}$ & 8 \\
\hline $\begin{array}{l}\text { Occasionally } \\
\text { consulted }\end{array}$ & Power and Interdependence & 1977 & Book & 242 \\
\hline $\begin{array}{l}\text { Publications } \\
\text { consulted and } \\
\text { subsequently } \\
\text { discarded } \\
\text { (due to } \\
\text { relevance or } \\
\text { difficulties } \\
\text { with access) }\end{array}$ & 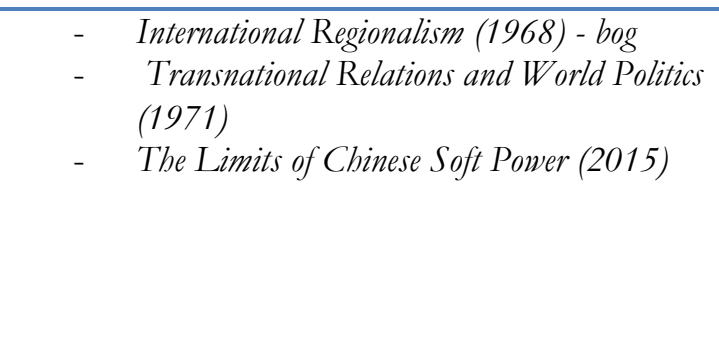 & & & \\
\hline
\end{tabular}


Frequency of different types of use of the word public)

\section{Wilson's use of the word 'public'}

\begin{tabular}{|l|c|}
\hline Categories of use (codes) & Occurrences \\
\hline Public men (man) & 4 \\
\hline Public opinion & 4 \\
\hline People (the public) & 4 \\
\hline Public investigation & 3 \\
\hline Quality/platform (in public for example 'public speech') & 3 \\
\hline Public interest & 3 \\
\hline Public assets (or public debt) & 3 \\
\hline Public mind & 2 \\
\hline Public thought & 2 \\
\hline Public motives & 1 \\
\hline Public inclination & 1 \\
\hline Public weal & 1 \\
\hline Public lands & 1 \\
\hline Public service & 1 \\
\hline Public policy & 1 \\
\hline Public dangers & 1 \\
\hline Public moral & 1 \\
\hline Public affairs & 1 \\
\hline Public works & 1 \\
\hline Public necessity & 1 \\
\hline Public institution (i.e. law, school etc.) & 1 \\
\hline Public regulation & 1 \\
\hline
\end{tabular}

\section{Nicolson's use of the word 'public'}

\begin{tabular}{|lc|}
\hline Categories of use (codes) & Occurrences \\
\hline Public opinion & 45 \\
\hline People (the public) & 13 \\
\hline Public life (of a person or 'the public life') & 8 \\
\hline Public institution (schools, law etc.) & 5 \\
\hline Public mind & 5 \\
\hline Quality/platform (in public for example 'public speech') & 4 \\
\hline Public questions/affairs etc. & 3 \\
\hline Public interest & 3 \\
\hline Public approval & 2 \\
\hline Public service & 2 \\
\hline
\end{tabular}




\begin{tabular}{|ll|}
\hline Public assets (or public debt) & 1 \\
\hline Public manner & 1 \\
\hline Public works & 1 \\
\hline Public business & 1 \\
\hline Public documents & 1 \\
\hline Public duty & 1 \\
\hline Public ignorance & 1 \\
\hline Public repudience & 1 \\
\hline Public debate & 1 \\
\hline Public protest & 1 \\
\hline Public responsibility & 1 \\
\hline Public lethargy & 1 \\
\hline Public menace & 1 \\
\hline Public estimate & 1 \\
\hline
\end{tabular}

\section{Kissinger's use of the word 'public'}

\begin{tabular}{|l|l|}
\hline Categories of use (codes) & Occurrences \\
\hline Public opinion & 49 \\
\hline People (the public) & 40 \\
\hline Quality/platform (in public for example 'public speech') & 36 \\
\hline Public support & 16 \\
\hline Public mood & 6 \\
\hline Public service & 5 \\
\hline Public life (of a person or 'the public life) & 4 \\
\hline Public protest & 4 \\
\hline Public accept (or public recognition) & 3 \\
\hline Public pressure & 3 \\
\hline Public relations & 2 \\
\hline Public criticism & 2 \\
\hline Public (reaction, reactions) & 2 \\
\hline Public figures & 2 \\
\hline Public career & 1 \\
\hline Public mythology & 1 \\
\hline Public conversion & 1 \\
\hline Public temper & 1 \\
\hline Public role & 1 \\
\hline Public expectation & 1 \\
\hline Public passions & 1 \\
\hline Public wounds & 1 \\
\hline Public trust (or confidence) & 1 \\
\hline
\end{tabular}




\begin{tabular}{|ll|}
\hline Public weal & 1 \\
\hline Public moral & 1 \\
\hline Public institution (law, schools, institution) & 1 \\
\hline Public sentiment & 1 \\
\hline Public outrage & 1 \\
\hline Public servant & 1 \\
\hline Public disillusion & 1 \\
\hline Public responsibility & 1 \\
\hline Public memory & 1 \\
\hline Public advisor & 1 \\
\hline
\end{tabular}

\section{Nye's use of the word 'public'}

\begin{tabular}{|lc|}
\hline Categories of use (codes) & Occurrences \\
\hline Public diplomacy & 102 \\
\hline People (the public) & 45 \\
\hline Public opinion & 22 \\
\hline Public good & 26 \\
\hline Public relations & 4 \\
\hline $\begin{array}{l}\text { Quality/platform (in public for example } \\
\text { 'public speech') }\end{array}$ & 3 \\
\hline Public support & 3 \\
\hline Public spirit & 2 \\
\hline Public image & 1 \\
\hline Public affairs & 1 \\
\hline Public health & 1 \\
\hline Public opposition & 1 \\
\hline
\end{tabular}

